\title{
Intervensi Penyelenggaraan Pemilukada: Regulasi, Sumberdaya dan Eksekusi
}

\author{
Sri Nuryanti
}

\begin{abstract}
The decision to have concurrent local election to be held on the $9^{\text {th }}$ December 2015 was part of a greater discourse to renew the electoral system so that it suit Indonesia best and able to address many issues especially dealing with efficiency in term of financing the local election and effectiveness in conducting local election. The discourse on local election on the late 2014 is important in order to see how the discourse is being thoroughly discussed especially based on the fact that there were many evidences of the so called low quality of local leader resulted from direct local election. This study will address the direct local election with giving emphasize on the ability of local human resources, local financial support and the implementation of local election. This article shows the need of regulative as well as technical interventions so that the local elections in those various condition will resulted at the good quality of local leaders.
\end{abstract}

\section{Keywords:}

local election; regulation; human resources.

\begin{abstract}
Abstrak
Keputusan untuk menyelenggarakan pilkada serentak yang diadakan pada tanggal 9 Desember 2015 merupakan bagian dari diskursus besar untuk memperbaharui sistem pemilu sehingga sistem itu paling sesuai dengan Indonesia dan khususnya mampu menjawab berbagai isu khususnya terkait dengan efisiensi dari segi pembiayaan pilkada dan efektifitas penyelenggaraan pilkada. Diskursus pilkada yang muncul di akhir 2014 penting untuk melihat bagaimana diskursus itu telah didiskusikan menyeluruh khususnya berdasarkan fakta bahwa ada banyak pemimpin lokal yang mempunyai kualitas rendah yang dihasilkan oleh pilkada yang diselenggarakan secara langsung. Kajian ini akan mengupas intervensi penyelenggaraan pilkada langsung, dengan memperhatikan kemampuan sumberdaya daerah, kemampuan keuangan dan pelaksanaan pilkada di lapangan. Tulisan ini mengisyaratkan perlunya intervensi baik regulatif maupun teknis agar pilkada yang diselenggarakan di daerah dengan beragam kondisi tersebut dapat menghasilkan kepala daerah dan wakil kepala daerah yang lebih berkualitas.
\end{abstract}

\section{Kata kunci:}

pemilukada; regulasi; sumberdaya.

\footnotetext{
- Peneliti di Lembaga Ilmu Pengetahuan Indonesia. Email: yanti8270@gmail.com
} 


\section{Pendahuluan}

Penyelenggaraan pemilu kepala daerah dari tahun ke tahun masih memunculkan persoalan. Baik persoalan yang berkaitan dengan kesiapan daerah dalam menyelenggarakan pemilu kepala daerah, persoalan pelaksanaan jadwal, tahapan dan program pemilu kepala daerah, pemenuhan persyaratan calon kepala daerah maupun wakil kepala daerah dan persoalan lain yang berkaitan dengan eksekusi di lapangan. Terkait dengan hal ini, Puslit Politik LIPI telah melakukan penelitian mengenai Evaluasi Penyelenggaraan Pemilu Kepala Daerah di tingkat Kabupaten/Kota (tahun 2012), Evaluasi Penyelenggaraan Pemilu Kepala Daerah Asimetris di tingkat Provinsi (tahun 2013) dan Desain Pemilu Kepala Daerah Asimetris Menuju Tatakelola Pemerintahan Daerah yang Demokratis, Akuntabel dan Berkelanjutan (tahun 2014). Tulisan ini merupakan analisis atas permasalahan penyelenggaraan pemilu kepala daerah dengan mempertimbangkan aspek kesiapan daerah, aspek pengelolaan sumber daya dalam penyelenggaraan pemilu kepala daerah, aspek pemenuhan persyaratan kepala daerah dan wakil kepala daerah yang secara khusus dilihat dari ketentuan undangundang mengenai persyaratan calon kepala daerah dan wakil kepala daerah.

Dilihat dari dinamika penyelenggaraan pemilu kepala daerah yang diselenggarakan sejak tahun 2005 menarik untuk diamati. Semenjak 2005 sampai 2014 penyelenggaraan pemilu kepala daerah berdasar pada UndangUndang Nomor 32 Tahun 2004. Sesuai dengan ketentuan Undang-Undang Nomor 32 Tahun 2004 tentang Pemerintahan Daerah, kepala daerah dipilih secara langsung, sehingga sering disebut dengan pilkada langsung. Namun dengan keluarnya Undang-Undang Nomor 22 Tahun 2007, pilkada langsung ini menjadi bagian dari rezim pemilu, maka istilah yang dipakai menjadi pemilukada. Dinamika pemilukada silih berganti mewarnai penyelenggaraan pemilukada. Pada tahun 2015, istilah pemilukada berubah menjadi Pemilihan Gubernur dan Wakil Gubernur, Bupati dan Wakil Bupati dan Walikota dan Wakil Walikota dengan keluarnya Undang-Undang Nomor 8 Tahun 2015. Nomenklatur ini secara esensial tidak mengubah tatacara pemilihan yaitu dilaksanakan secara langsung, meskipun pernah ada wacana untuk mengembalikan metode pemilihan kepala daerah ke tangan DPRD.

Diskursus mengenai adanya keinginan untuk mengembalikan metode pemilihan kepala daerah dari pemungutan suara langsung menjadi dipilih oleh DPRD telah muncul di Sidang Paripurna DPR RI tanggal 24 September 2014. Hal itu konon didasari alasan biaya mahal, potensi konflik yang konon diakibatkan karena pemilukada dan pemilukada langsung yang dianggap tidak menjamin munculnya kepala daerah yang baik. Menurut data Dirjen Otonomi Daerah Kementerian Dalam Negeri Republik Indonesia, sampai dengan tahun 2013, terdapat 954 pasangan kepala daerah baik di provinsi maupun kabupaten/ kota yang terpilih, namun kemudian terjerat permasalahan hukum. ${ }^{1}$ Ini kemungkinan yang memperkuat alasan waktu itu, dimana ada keinginan untuk mengembalikan pemilihan kepala daerah ke tangan DPRD. Disahkannya Undang-Undang Nomor 23 Tahun 2014 menuai pro kontra yang tajam. Sebagian mengatakan bahwa pemilukada melalui DPRD adalah untuk menghindari money politics yang begitu marak terjadi. Sebagian besar menentang, bahwa pemilihan kepala daerah oleh DPRD pun tidak mustahil sarat dengan politik uang. Menyikapi soal ini, sudah setidaknya tiga tahun terakhir, Puslit Politik LIPI telah melakukan penelitian tentang menata ulang pemilukada untuk menuju tatakelola pemerintahan yang

\footnotetext{
Prof. Dr. H. Djohermansyah Djohan, M.A., Dirjen Otonomi Daerah Kementerian Dalam Negeri Republik Indonesia, "Dinamika Dan Ekses Pilkada Langsung," tanpa halaman.
} 
demokratis, akuntabel dan efektif. Sehubungan dengan hal itu, makalah ini akan menyoroti perkembangan permasalahan pemilukada yang diambilkan dari hasil penelitian tim Pemilukada P2P LIPI ${ }^{2}$ khususnya mengenai evaluasi penyelenggaraan pemilukada di tingkat Kabupaten/Kota dan Provinsi, terkait kesiapan wilayah untuk menyelenggarakan pemilukada dan penambahan analisis tentang prospek pemilukada ke depan khususnya untuk membangun pemerintahan yang demokratis, stabil dan efektif.

Sebagaimana bunyi pada Pasal 56 UU Nomor 32 Tahun 2004 tentang Pemerintah Daerah, untuk memilih kepala daerah di tingkat provinsi maupun kabupaten kota dilakukan melalui pemungutan suara secara langsung oleh masyarakat yang mempunyai hak pilih di wilayah yang menyelenggarakan pemilukada. Pemilihan kepala daerah secara langsung ini, apabila dilihat dari teori, maka pemilukada langsung ini mempunyai legitimasi yang sangat kuat karena kepala daerah terpilih, dipilih langsung oleh konstituennya. Konstituen dalam hal ini diberi kesempatan untuk turut serta menentukan pemerintahan daerahnya. Dengan demikian, kepala daerah terpilih selain memiliki legitimasi yang kuat, juga diharapkan memunculkan kepala daerah yang mempunyai orientasi untuk meningkatkan kesejahteraan rakyatnya.

Perlu disampaikan bahwa sejak 1 Juni 2005 hingga 6 Agustus 2013, telah berlangsung 954 pemilukada di tingkat provinsi maupun kabupaten/kota. ${ }^{3}$ Ditambah dengan pemilukada Gubernur Lampung yang penyelenggaraannya

\footnotetext{
2 Tim Penelitian Pemilukada Puslit Politik LIPI tahun 2014 terdiri dari Dr. Kurniawati Hastuti Dewi (Koord), Prof. Dr. Indria Samego, Drs. Afadlal, MA, Sri Nuryanti, SIP,MA, Pandu Yuhsina Adaba, SIP, dan Nyimas Latifah Letty Aziz, SE, MSc.

3 Prof. Dr. H. Djohermansyah Djohan, MA, Dirjen Otonomi Daerah Kementerian Dalam Negeri Republik Indonesia, "Dinamika Dan Ekses Pilkada Langsung," paper disampaikan dalam FGD tim Pemilukada, 26 Agustus 2013 di LIPI Jakarta, tanpa halaman
}

bersamaan dengan pemilu anggota DPR, DPD dan DPRD 2014.

Dalam perkembangannya, pemilukada menjadi polemik yang mengerucut pada pro dan kontra. Para akademisi ${ }^{4}$ dan pemerhati politik seperti Perludem, ${ }^{5}$ mendukung pemilukada karena pemilihan kepala daerah secara langsung di provinsi maupun kabupaten/kota selaras dengan sistem presidensiil. Sementara itu, pemerintah memiliki pendapat berbeda bahwa pemilihan kepala daerah secara langsung tidak bisa disebut sebagai satusatunya format pemilihan yang "demokratis". Karena jika kata "demokratis" dalam Perubahan II Undang-Undang Dasar Negara Republik Indonesia 1945 pasal 18 ayat (4) hanya dimaknai sebagai pemilihan secara langsung semata, bertentangan dengan konstitusi karena pasal 18B ayat 1 UUD 1945 menghormati keragaman, kekhususan, dan keistimewaan daerah-daerah di Indonesia dalam bingkai Negara kesatuan, yang melahirkan desain pemilihan kepala daerah sebagai pilkada "asimetris" karena kekhususannya. ${ }^{6}$ Pengertian "asimetris" karena kekhususannya atau karena adanya Undang-Undang yang berlaku khusus mengatur penyelenggaraan pemilukada di wilayah itu. Hal ini merujuk pada adanya

\footnotetext{
4 Sebagai contoh Hasyim Asy'ari, "Mempertahankan Pilkada Langsung," Makalah disampaikan pada Focus Group Discussion (FGD), "Evaluasi Format Pilkada", diselenggarakan oleh Pusat Penelitian Politik (P2P), Lembaga Ilmu Pengetahuan Indonesia (LIPI), Jakarta, Kamis, 4 April 2013; Reza Syawawi dan Khoirunnisa Nur Agustyati, "Membunuh Demokrasi Lokal: Mengembalikan Pemilihan Gubernur Kepada DPRD Provinsi," halaman 16

5 Titi Anggraini dkk, Menata Kembali Pengaturan Pemilukada (Jakarta: Perludem, 2011), halaman 24.

Posisi Perludem didasarkan argumen Jimly Asshiddiqie bahwa ketentuan pasal dalam konstitusi harus dimaknai sejalan dan tidak boleh bertentangan, maka kata "demokratis" dalam pasal 18 ayat (4), harus sejalan dengan amandemen III UUD 1945 pasal 6A ayat (1) yang berbunyi "Presiden dan Wakil Presiden dipilih dalam satu pasangan secara langsung oleh rakyat".

6 Pendapat Prof. Dr. H. Djohermansyah Djohan, M.A., Dirjen Otonomi Daerah Kementerian Dalam Negeri Republik Indonesia, “Dinamika Dan Ekses Pilkada Langsung," tanpa halaman.
} 
penyelenggaraan pemilukada di wilayah Aceh yang menggunakan ketentuan Qonun dimana setiap calon kepala daerah harus mengikuti tes baca Al Qur'an, atau menggunakan formula lima puluh persen plus satu untuk penentuan pemenang pemilukada DKI, penggunaan persetujuan Majelis Rakyat Papua khususnya mengenai syarat "asli Papua" bagi calon kepala daerah dan wakil kepala daerah Papua, dan DIY yang tidak dipilih tetapi menggunakan “penetapan” yaitu Sri Sultan Hamengku Buwono sebagai Gubernur dan Pakualam sebagai Wakil Gubernur.

Di antara pro-dan kontra mengenai emilukada di provinsi maupun kabupaten/ kota, tim kajian pemilukada Pusat Penelitian Politik LIPI memposisikan untuk mendukung pelaksanaan pemilihan kepala daerah secara langsung (pemilukada) baik di provinsi maupun kabupaten/kota. Posisi ini didasari oleh hasil kajian empiris selama tiga tahun berturut-turut. Kajian tahun pertama (2012) fokus pada evaluasi format pemilukada di tingkat kabupaten/kota, yang menghasilkan indikasi perlunya pemilukada asimetris di tingkat kabupaten/kota dengan memperhatikan asek sosial budaya masyarakat setempat. ${ }^{7}$ Kajian tahun kedua (2013) fokus pada evaluasi format pemilukada di tingkat provinsi, yang salah satunya menemukan permasalahan mendasar mengenai desain institusional pemilukada di dalam Undang-Undang Nomor 32 Tahun 2004 yang menggunakan model simetris yaitu menyeragamkan kebijakan pemilukada untuk semua provinsi dan kabupaten/kota di Indonesia. Padahal kondisi setiap daerah dari segi kemampuan sumber daya manusia dan keuangan daerah tidak merata, sehingga mengakibatkan pelaksanaan dan hasil pemilukada diliputi

\footnotetext{
Tim Penelitian Pemilukada Pusat Penelitian Politik LIPI (Prof. Dr. Indria Samego, Dra. Sri Nuryanti, MA., Dr. Tri Ratnawati, Drs. Afadlal, MA, Pandu Yusina Adaba S.Ip., Dini Suryani S.Ip), “Evaluasi Praktik Pemilukada Langsung di Kabupaten/Kota dan Beberapa Usulan Penyempurnaan ke Depan," Executive Summary, Jakarta, 2012.
}

berbagai masalah. ${ }^{8}$ Salah satu hasil kajian tahun kedua (2013) adalah memetakan kesiapan provinsi dalam melaksanakan pemilukada berdasarkan kemampuan sumber daya manusia (Indeks Pembangunan Manusia) dan kemampuan keuangan daerah dari LEVEL I sampai dengan LEVEL VI, ${ }^{9}$ kemudian merekomendasikan model pemilukada asimetris di tingkat provinsi. Adapun pengertian mengenai kemampuan sumber daya daerah dan kemampuan keuangan daerah dapat dikategorisasikan bahwa daerah dengan kategori LEVEL I (IPM TINGGI Kemampuan Keuangan KUAT) dapat melakukan pemilukada, Daerah dengan kategori LEVEL II (IPM TINGGI Kemampuan Keuangan LEMAH) dapat melakukan pemilukada, Sementara itu, daerah dengan kategori LEVEL III (IPM SEDANG Kemampuan Keuangan KUAT) dapat melakukan pemilukada, Pada daerah dengan kategori LEVEL IV (IPM SEDANG Kemampuan Keuangan LEMAH) dapat melakukan pemilukada tetapi kemungkinan banyak masalah muncul, Sementara itu, daerah dengan kategori LEVEL V (IPM RENDAH Kemampuan Keuangan KUAT) tidak perlu langsung mengikuti pemilukada, di dahului dengan tahap transisi, dan daerah pada kategori LEVEL VI(IPM RENDAH Kemampuan Keuangan LEMAH) tidak perlu langsung mengikuti pemilukada, didahului dengan tahap transisi. ${ }^{10}$

\footnotetext{
Tim Penelitian Pemilukada Pusat Penelitian Politik LIPI (Dr. Kurniawati Hastuti Dewi, Prof. Dr. Indria Samego, Dra. Sri Nuryanti, MA., Drs. Afadlal, MA., Pandu Yusina Adaba S.Ip., Dini Suryani, S.Ip), Evaluasi Format Pemilukada Menuju Pemerintahan Daerah yang Baik dan Efektif di tingkat Provinsi, Policy Paper, Pusat Penelitian Politik LIPI, Jakarta, 2013, belum diterbitkan.

9 Lihat Kurniawati Hastuti Dewi, "Pemilihan Kepala Daerah Provinsi: Perubahan, Kesinambungan dan Pemetaan Kesiapan Daerah," dalam Kurniawahi Hastuti Dewi (ed.), Evaluasi Format Pemilukada Menuju Pemerintahan Daerah yang Baik dan Efektif di tingkat Provinsi, Laporan penelitian tim Pemilukada, Pusat Penelitian Politik LIPI, Jakarta, 2013, tanpa halaman (belum diterbitkan).

${ }^{10}$ Kurniawati Hastuti Dewi, dkk, “Kesimpulan dan Rekomendasi," dalam Kurniawati Hastuti Dewi (ed.), Evaluasi Format Pemilukada Menuju Pemerintahan Daerah yang Baik dan Efektif di tingkat Provinsi, Laporan
} 
Melalui kajian berturut-turut ini, tim berpendapat bahwa menelaah pemilukada tidak cukup menggunakan pendekatan politik semata, tetapi perlu pendekatan menyeluruh mempertimbangkan aspek sosial, ekonomi, dan budaya masyarakat setempat. Persoalannya adalah, dalam Undang-Undang Nomor 32 Tahun 2004, aspek sosial, ekonomi, budaya sebagai fakta keragaman daerah ini tidak dipertimbangkan di dalam menyusun desain pemilukada. Hal inilah yang menjadi fokus kajian tahun ketiga (2014), di mana tim berusaha menata dan merekomendasikan model pemilukada di kabupaten/kota dan provinsi yang tepat untuk Indonesia. Rekomendasi atas studi tentang pemilukada di Puslit Politik LIPI tentunya sejalan dengan upaya untuk mewujudkan pemerintahan yang demokratis, stabil dan efektif.

\section{Telaah Filosofis Pemilukada Langsung}

Suatu negara disebut demokratis antara lain mensyaratkan adanya perlindungan konstitusional terhadap hak-hak warga negara, adanya pemilu yang bebas, kebebasan berserikat, berkumpul, menyatakan pendapat. Sejalan dengan hal ini, apabila dilihat dari prinsip tatakelola pemerintahan yang baik, maka diperlukan partisipasi aktif warga masyarakat dalam pemerintahan, adanya penegakan hukum, pengaplikasian prinsipprinsip transparansi, responsif terhadap kebutuhan masyarakat, menerapkan keadilan dan perlakuan yang sama untuk semua orang, pengelolaan kekuasaan yang efektif dan dapat dipertanggungjawabkan. Oleh sebab itu, terkait pemilihan kepala daerah langsung diharapkan akan meningkatkan partisipasi dan keterlibatan masyarakat dalam proses politik di daerah yang demokratis dalam menentukan kepala daerahnya supaya menghasilkan

penelitian tim Penelitian Pemilukada, Pusat Penelitian Politik LIPI, Jakarta, 2013, tanpa halaman (belum diterbitkan). pemerintah daerah yang aspiratif dan memiliki komitmen kuat meningkatkan kesejahteraan masyarakat. Ada harapan akan adanya timbal balik positif antara peningkatan partisipasi politik masyarakat melalui pemilukada dengan perubahan kinerja pemerintah daerah yang lebih baik. ${ }^{11} \mathrm{Jadi}$, secara ideal pemilukada dilihat sebagai mekanisme yang memungkinkan tercapainya kesejahteraan masyarakat secara efektif dan cepat.

Sebagaimana diketahui bahwa urusan pemerintahan daerah adalah berasal dari kekuasaan pemerintahan yang berada di tangan presiden. Apabila dilihat dari bunyi Amandemen III UUD 1945 khususnya Pasal 6 Ayat (1) UUD 1945 menyatakan "Presiden dan wakil presiden dipilih dalam satu pasangan secara langsung oleh rakyat", telah menggantikan UUD 1945 sebelum amandemen yang memberikan kewenangan pada MPR untuk memilih presiden dan wakil presiden. Dari sini, nampak jelas adanya konsistensi tiap pasal dalam UUD 1945 hasil amandemen III, untuk memperkuat sistem pemerintahan presidensiil. Dalam kerangka itulah, upaya penataan pemilukada berpijak pada memperkuat sistim pemerintahan presidensiil. Oleh karena pemilihan presiden telah diserahkan langsung kepada rakyat sebagai pemilik kedaulatan tertinggi, maka jabatan-jabatan dibawahnya termasuk kepala daerah provinsi dan kabupaten/kota sebagai kepala daerah otonom, yang memperoleh kewenengan oleh konstitusi, sebaiknya dipilih langsung oleh rakyat.

Dengan demikian filosofi pemilihan kepala daerah secara langsung di kabupaten/ kota dan provinsi adalah untuk mendudukkan satuan pemerintah daerah pada posisi yang kuat sebagai salah satu bagian struktur ketatanegaraan dalam Negara Kesatuan Republik Indonesia yang memperoleh

\footnotetext{
${ }^{11}$ Vedi R. Hadiz, Localising Power in Post-Authoritarian Indonesia: A Southeast Asia Perspective (Stanford California: Stanford University Press, 2010), halaman121.
} 
legitimasi dari konstitusi (bukan pemberian dari pemerintah pusat), supaya dapat menghasilkan gubernur, bupati dan walikota yang bekerja sepenuhnya bagi kesejahteraan rakyat. Selain menjaga dan memperkuat sistem pemerintahan presidensial. Bagian berikutnya akan memaparkan dan menegaskan konsep mengenai pemilihan kepala daerah secara langsung dengan model 'asimetris' yang digagas oleh tim peneliti pemilukada LIPI yang mempertimbangkan aspek asimetris dari sisi kemampuan sumberdaya masyarakat dan kemampuan keuangan daerah sebagaimana yang sudah disinggung di atas. Asimetrisme yang diusulkan tim peneliti pemilukada LIPI adalah menyangkut desain pemilihan kepala daerah secara langsung. Asimetris yang dimaksud di sini bukan atas dasar konstitusi (de jure) seperti pasal 18B Ayat 1 UUD 1945 yang menghormati keragaman, kekhususan, dan keistimewaan daerah-daerah di Indonesia dalam bingkai Negara kesatuan, sehingga memberikan keistimewaan dalam mekanisme pemilukada langsung di Daerah Istimewa Aceh, Daerah Istimewa Yogyakarta, Provinsi Papua Barat dan DKI Jakarta. Pemilihan kepala daerah secara langsung dengan model asimetris, usulan tim peneliti pemilukada LIPI, didasarkan pada fakta kondisi daerah (de facto) yang dapat dilihat dari aspek sosial berupa kemampuan sumber daya manusia daerah yang tecermin dari Indeks Pembangunan Manusia (angka harapan hidup, angka melek huruf, pendikan), ekonomi yang tecermin dari kemampuan keuangan daerah, dan memperhatikan aspek budaya.

Hasil kajian tahun 2013 yang fokus pada pemilukada provinsi diantaranya adalah (i) keberhasilan memetakan kesiapan provinsi dalam melaksanakan pemilukada atas dasar keragaman daerah khususnya kemampuan sumber daya manusia, dan (ii) merekomendasikan model pemilukada asimetris di tingkat provinsi. ${ }^{12}$ Kajian

${ }^{12}$ Kurniawati Hastuti Dewi, dkk, “Kesimpulan dan tim peneliti Pusat Penelitian Politik LIPI mengenai evaluasi format pemilukada di kabupaten/kota dan provinsi selama dua tahun berturut-turut tersebut memiliki benang merah yang sama yaitu: bahwa setiap daerah memiliki kekhasan baik dari segi sosial budaya, sumber daya manusia, maupun kemampuan keuangan daerah yang harus dipertimbangkan masak-masak dalam membuat desain pemilukada yang paling tepat dengan keragaman kondisi Indonesia.

Asimetri ideal menurut Tarlton (1965: 869) dalam sistem federal merupakan kondisi unit politik yang memiliki perbedaan perhatian, karakter, yang eksis dan meliputi komunitas secara keseluruhan. ${ }^{13}$ Pengertian tentang desentralisasi asimetris lainnya dikemukakan oleh Jennie Litvack, Junaid Ahmad, Richard Bird (1998: 23) dari the World Bank yang mengatakan bahwa perbedaan ekonomi, demografi, dan kondisi sosial dalam daerahdaerah tertentu mengakibatkan kebijakan politik atau desentralisasi yang "satu ukuran untuk semua" (one size fits all) tidak mungkin diterapkan. Oleh karena itu untuk mengakomodasi kebutuhan yang berbeda-beda itu diperlukan kebijakan, khususnya dalam hal desentralisasi dengan prinsip desentralisasi asimetris yaitu yang memperlakukan unit yang berbeda (kondisinya) secara berbeda pula untuk mencapai tujuan yang sama. ${ }^{14}$

Kajian dari Jurusan Politik dan Pemerintahan Universitas Gadjah Mada (UGM) menyebutkan setidaknya lima model yang

Rekomendasi," dalam Kurniawati Hastuti Dewi (ed.), Evaluasi Format Pemilukada Menuju Pemerintahan Daerah yang Baik dan Efektif di tingkat Provinsi, Laporan penelitian tim Penelitian Pemilukada, Pusat Penelitian Politik LIPI, Jakarta, 2013, tanpa halaman

${ }^{13}$ Charles D. Tarlton, "Symmetry and Assymetry as Element of Federalism: A Theoretical Speculation", the Journal of Politics, Vol. 27 (1965): 869.

${ }^{14}$ Jennie Litvack, Junaid Ahmad, Richard Bird, “Rethinking Decentralization in Developing Countries", The World Bank Sector Studies Series, September 1998, http://internationalbudget.org/wp-content/uploads/ Rethinking-Decentralization-in-Developing-Countries. pdf (diakses 10 April 2014), halaman 23. 
menjadi basis asimetrisme yang dipraktikkan di Indonesia. Pertama, model asimetrisme yang didasarkan pada kekhasan daerah karena faktor politik terkait sejarah konflik yang panjang misalnya di Aceh dan Papua. Kedua, model asimetrisme yang didasarkan pada kekhasan daerah berbasis sosio-kultural seperti di Daerah Istimewa Yogyakarta. Ketiga, model asimetrisme yang didasarkan kekhasan daerah berbasis geografis-strategis misalnya di daerah perbatasan seperti di Kalimantan Barat, Papua, Kepulauan Riau. Keempat, model asimetrisme yang didasarkan pada kekhasan daerah berbasis potensi dan pertumbuhan ekonomi seperti di Papua, Aceh, Kalimantan Barat, Batam, Jakarta. Kelima, model asimetrisme berbasis tingkat akselerasi pembangunan dan kapasita governability seperti di Papua. ${ }^{15}$

Pemilihan kepala daerah secara langsung dengan model asimetris, usulan tim peneliti pemilukada LIPI, didasarkan pada fakta kondisi daerah (defacto) yang dapat dilihat dari aspek sosial berupa kemampuan sumber daya manusia daerah yang tecermin dari Indeks Pembangunan Manusia (angka harapan hidup, angka melek huruf, pendikan), ekonomi yang tecermin dari kemampuan keuangan daerah, dan memperhatikan aspek budaya. Mutu demokrasi, salah satunya demokrasi langsung seperti halnya pemilihan kepala daerah, tidak saja ditentukan oleh kualitas politik ("quality of politics") tetapi juga oleh kualitas masyarakat ("quality of society") sebagaimana ditegaskan oleh David F.J. Campbell. ${ }^{16}$

Kajian tim peneliti Pusat Penelitian Politik LIPI mengenai evaluasi format pemilukada di kabupaten/kota (tahun 2012) dan provinsi

\footnotetext{
${ }^{15}$ Tim Peneliti Jurusan Politik dan Pemerintahan UGM, Laporan Akhir Desentralisasi Asimetris Yang Menyejahterakan: Aceh dan Papua (Yogyakarta: Jurusan Politik dan Pemerintahan Universitas Gadjah Mada, 2012), halaman 9-10.

${ }^{16}$ David F.J. Campbell, 29 September 2008, halaman 35, http://www.democracyranking.org/downloads/basic_ concept_democracy_ranking_2008_A4.pdf (diakses 11 october 2013).
}

(tahun 2013) menunjukkan bahwa baik di Kabupaten/Kota maupun Provinsi mempunyai kemampuan sumberdaya manusia dan kemampuan keuangan yang beragam. Kondisi inilah yang melatar belakangi pemikiran perlunya mengklasifikasikan daerah-daerah yang siap menyelenggarakan pemilukada dan daerahdaerah yang memerlukan pendampingan dalam penyelenggaraan pemilukada. Selanjutnya membahas kualitas demokrasi (2004) O' Donnel menegaskan pandangannya, bahwa salah satu komponen penting bahkan sangat dasar dari demokrasi, yang selama ini kerap diabaikan orang adalah, manusia dalam hal ini warga Negara sebagai agen (agency); dimana O'Donnel percaya ada hubungan erat antara demokrasi, pembangunan manusia (Human Development), dan hak asasi manusia (Human Rights). ${ }^{17}$

O'Donnel menegaskan bahwa dalam sebuah sistim demokrasi, penguasa harus dapat memenuhi tiga macam akuntabilitas. Pertama, akuntabilitas keterpilihan vertikal ("vertical electoral accountability") dihasilkan dari pemilihan umum yang jujur dan institusional dimana warga negara dapat berpindah partai politik dan memilih pejabat pemerintah. Kedua, akuntabilitas masyarakat ("societal accountability") dimana warga negara atau kelompok warga negara dapat menempuh jalur hukum untuk mendesak negara agar mampu mencegah, mengatasi dan menghukum pejabat publik yang melanggar hukum. Ketiga, akuntabilitas horizontal ("horizontal accountability") dimana terdapat lembaga negara yang memiliki kewenangan mencegah, mengatasi, dan menindak pejabat atau lembaga negara yang melanggar hukum. ${ }^{18}$ Menurut

\footnotetext{
${ }^{17}$ Guillermo O’Donnell, “Human Development, Human Rights, and Democracy," dalam Guillermo O'Donnell, Jorge Vargas Cullell, Osvaldo M. Iazzetta (eds.), The Quality of Democracy Theory and Applications, (USA: University of Notre Dame Press, 2004), halaman 9-10.

${ }^{18}$ Guillermo A. O'Donnell, “Why the Rule of Law,” Journal of Democracy, Vol. 15, No. 4 (Oktober 2004), halaman 37, http://muse.jhu.edu/journals/jod/summary/ v015/15.4odonnell.html ( diakses 14 Oktober 2013)
} 
O'Donnel, jika akuntabilitas keterpilihan vertikal mutlak ada dalam sebuah sistim demokrasi, maka akuntabilitas masyarakat dan akuntabilitas horizontal sangat beragam kondisi dan kefektifitasannya, misalnya satu masyarakat bisa saja tidak memiliki karakter yang kritis dibarengi dengan kondisi kelembagaan negara yang lemah, sehingga dapat dikategorikan sebagai demokrasi dengan mutu rendah ("low-quality democracy"). ${ }^{19}$

Oleh sebab itu, untuk meningkatkan kualitas kehidupan berdemokrasi, diperlukan penataan proses politiknya dengan melakukan intervensi-intervensi yang diharapkan dapat memunculkan hasil yang bagus dan mendukung pemerintahan yang stabil dan efektif.

\section{Menata Sistem Pemilukada}

Sebagaimana diketahui bahwa penyelenggaraan pemilukada selama ini, masih ada permasalahan terkaitdengan berbagai hal baik dari batasan-batasan ketentuan perundangan, aspek penyelenggara, penyelenggaraan dan peran serta pemangku kepentingan lain. Untuk itu diperlukan intervensi yang sifatnya regulatif dan sifatnya teknis. Intervensi regulatif diperlukan untuk memberikan masukan dan atau perubahan atas klausul di dalam UU dan/atau pengaturan lainnya agar proses penyelenggaraan pemilukada langsung dapat terselenggara dengan demokratis, dan hasil pemilukadanya mendukung pemerintahan yang stabil dan efektif

Tabel 1.

Intervensi Regulatif

\begin{tabular}{|c|l|l|l|}
\hline No & \multicolumn{1}{|c|}{ Tahapan } & \multicolumn{1}{|c|}{ Permasalahan } & \multicolumn{1}{|c|}{ Solusi } \\
\hline 1 & $\begin{array}{l}\text { Pra Tahapan: } \\
\text { Masa Akhir } \\
\text { Jabatan Kepala } \\
\text { Daerah }\end{array}$ & $\begin{array}{l}\text { Kadang terjadi politisasi krn } \\
\text { tergantung dengan DPRD }\end{array}$ & $\begin{array}{l}\text { KPU tidak dibebani keharusan untuk } \\
\text { menung u terlaks an an ya sid ang } \\
\text { paripurna DPRD }{ }^{21}\end{array}$ \\
\hline 2 & $\begin{array}{l}\text { Pembuatan } \\
\text { Daftar } \\
\text { Pemilih pada } \\
\text { Pemilukada }\end{array}$ & $\begin{array}{l}\text { Bermasalah apabila tidak ada } \\
\text { kerjasama dan sinkronisasi } \\
\text { data dari berbagai sumber. } \\
\text { Susah mendapatkan data yang } \\
\text { mutakhir, komprehensif dan } \\
\text { akurat. }^{22}\end{array}$ & $\begin{array}{l}\text { Pemutakhiran terus menerus d an } \\
\text { penyandingan data dari sumber lain. }\end{array}$ \\
\hline 3 & $\begin{array}{l}\text { Tahap } \\
\text { Pencalonan: } \\
\text { Pemenuhan } \\
\text { syarat } \\
\text { pencalonan }\end{array}$ & $\begin{array}{l}\text { Dukungan ganda, status } \\
\text { legal formal partai politik, } \\
\text { konflik kepemimpinan pada } \\
\text { partai politik atau pemenuhan } \\
\text { dukungan perseorangan }\end{array}$ & $\begin{array}{l}\text { Ketentuan Undang-Undang tentang partai } \\
\text { politik yang boleh mencalonkan adalah } \\
\text { partai politikyang mempunyai kedudukan } \\
\text { hukum yang sah dari Kemenkumham }\end{array}$ \\
\hline
\end{tabular}

${ }^{19}$ Ibid.

${ }^{20}$ Di beberapa penyelenggaraan pemilu kepala daerah seperti di Kabupaten Mesuji, Kota Pekanbaru, Provinsi Lampung, telah terjadi politisisasi dalam hal penentuan tahapan, program dan jadwal penyelenggaraan pemilukada di daerah tersebut. Lihat Evaluasi Penyelenggaraan Pemilukada Tingkat Kabupaten/Kota, Laporan Penelitian P2P LIPI, 2012

${ }^{21}$ Dalam kasus yang menimpa Kabupaten Mesuji pada penyelenggaraan pemilukada tahun 2011 misalnya, KPU Kabupaten Mesuji dianggap bersalah oleh DPRD Mesuji karena penentuan Jadwal, Tahapan, Program Penyelenggaraan Pemilu Kepala Ddaerah tidak menunggu sampai Sidang Paripurna dilaksanakan oleh DPRD Mesuji.

${ }^{22}$ Mengenai hal ini, dapat diambil contoh penyelenggaraan pemilukada Kabupaten Mesuji dimana terdapat Wilayah Register 45 yaitu sebuah wilayah perkebunan yang dulu dikelola oleh PT. Inhutani, namun pada saat sekarang menjadi lahan yang banyak dihuni oleh penduduk pendatang dengan status kependudukan tidak jelas, khususnya di Moro-Moro dan sekitarnya. Lihat Lihat Evaluasi Penyelenggaraan Pemilukada Tingkat Kabupaten/Kota, Laporan Penelitian P2P LIPI, 2012, ibid 


\begin{tabular}{|c|c|c|c|}
\hline 4 & $\begin{array}{l}\text { Tahap } \\
\text { Pencalonan: } \\
\text { Pemenuhan } \\
\text { Syarat Calon }\end{array}$ & $\begin{array}{l}\text { Pemenuhan syarat pendidikan } \\
\text { minimal setingkat sekolah } \\
\text { lanjutan tingkat atas atau } \\
\text { sederajat; soal ketentuan tidak } \\
\text { pernah dijatuhi pidana dengan } \\
\text { ancaman pidana minimal } \\
\text { lima tahun; terkait verifikasi } \\
\text { atas persyaratan bahwa } \\
\text { calon mengenal daerahnya } \\
\text { dan dikenal masyarakat; } \\
\text { terkait penyerahan daftar } \\
\text { kekayaan pribadi dan bersedia } \\
\text { diumumkan; dengan posisi } \\
\text { incumbent. }{ }^{23}\end{array}$ & $\begin{array}{l}\text { Ketentuan pendidikan menjadi minimal } \\
\text { setingkat sarjana dan mempunyai } \\
\text { ketrampilan dibidang tatakelola atau } \\
\text { managemen yang dibuktikan dengan } \\
\text { sertifikat atau keterangan lain. Calon } \\
\text { yang sedang berperkara hukum, tidak } \\
\text { diperbolehkan mencalon menyampaikan } \\
\text { naskah akademis dan naskah usulan } \\
\text { program RPJMD. Pelaporan kekayaan, } \\
\text { dilampiridengan ditandatanganinya pakta } \\
\text { integritas dan pernyataan siap diaudit } \\
\text { apabila diperlukan untuk pengawasan } \\
\text { penggunaan anggaran negara. Adanya } \\
\text { mekanisme untuk tidak dimanfaatkannya } \\
\text { birokrasi dan fasilitas negara untuk } \\
\text { keperluan itu. }\end{array}$ \\
\hline 5 & Kampanye & $\begin{array}{l}\text { Penggunaan fasilitas negara } \\
\text { dan pengerahan birokrasi }{ }^{24}\end{array}$ & $\begin{array}{l}\text { Penegasan mengenai mekanisme yang } \\
\text { tidak memberi peluang penggunaan } \\
\text { fasilitasi daerah/negara oleh incumbent } \\
\text { yang mengatur tentang batas frekuensi } \\
\text { maksimal yaitu sekali saja. }\end{array}$ \\
\hline 6 & $\begin{array}{l}\text { Pemungutan } \\
\text { dan } \\
\text { Penghitungan } \\
\text { Suara } \\
\end{array}$ & $\begin{array}{l}\text { Menjajagi kemungkinan } \\
\text { digunakannya e voting dan } \\
\text { atau e counting technology }\end{array}$ & $\begin{array}{l}\text { Ketentuan UU ttg penggunaan TI dengan } \\
\text { dilakukan studi terlebih dahulu }\end{array}$ \\
\hline 7 & $\begin{array}{l}\text { Penyelesaian } \\
\text { sengketa } \\
\text { pemilukada }\end{array}$ & $\begin{array}{l}\text { Jalur sengketa tidak satu } \\
\text { pintu }\end{array}$ & $\begin{array}{l}\text { Ketentuan final dan mengikat pada } \\
\text { putusan MK, keputusan lembaga } \\
\text { hukum lain, tidak berpengaruh terhadap } \\
\text { keputusan MK }\end{array}$ \\
\hline
\end{tabular}

Sumber: Diolah dari berbagai sumber termasuk dari hasil penelitian LIPI tahun 2012 tentang evaluasi penyelenggaraan pemilukada di tingkat Kabupaten/Kota dan hasil penelitian LIPI tahun 2013 tentang Evaluasi Penyelenggaraan pemilukada Tingkat Provinsi

Tabel 1 berisi intervensi regulatif yang merupakan pemetaan permasalahan dari berbagai sumber data termasuk di dalamnya adalah hasil penelitian LIPI tahun 2012 tentang penyelenggaraan pemilu kepala daerah di tingkat kabupaten/kota dan hasil penelitian LIPI tahun 2013 tentang penyelenggaraan pemilu kepala daerah di tingkat provinsi .
Sedangkan intervensi teknis merupakan dokumen penunjang dan teknis penyelenggaraan yang akan menghasilkan Kepala Daerah yang tidak tersangkut masalah hukum, mempunyai kapabilitas untuk menjadi pemimpin daerah dan mempunyai integritas yang tinggi. Hal ini diperlukan apalagi dengan mengingat bahwa sebagai kepala daerah,

\footnotetext{
${ }^{23}$ Dari penyelenggaraan pemilukada di Kabupaten Lembata (NTT) menyangkut politisasi posisi incumbent, sementara pemilukada di Kabupaten Mesuji (Lampung) terkaita dengan tidak adanya ketentuan mengenai calon kepala daerah atau wakil kepala daerah yang bermasalah hukum, sehingga Kepala Daerah Terpilih harus dilantik di penjara. Lihat Lihat Evaluasi Penyelenggaraan Pemilukada Tingkat Kabupaten/Kota, Laporan Penelitian P2P LIPI, 2012, ibid.

${ }^{24}$ Dari penyelenggaraan pemilukada tingkat Provinsi di Bengkulu tahun 2010 misalnya ditengarai bahwa telah terjadi penggunaan fasilitas negara yang ditandai dengan terjadinya korupsi dana APBD yang dilakukan oleh Gubernur terpilih sehingga Gubernur Terpilih (Agusrin Najamudin) harus dipenjara. Lihat Evaluasi Penyelenggaraan Pemilukada Tingkat Provinsi, P2P LIPI, tahun 2013
} 
performanya akan diukur dengan berbagai evaluasi seperti adanya Evaluasi Kinerja Penyelenggaraan Pemerintahan Daerah (EKPPD), Evaluasi Kemampuan Otonomi Daerah (EKPOD), dan Evaluasi Daerah Otonom Baru (EDOB). ${ }^{20}$

\section{Proses Pemilukada}

Secara teoritik, pemilukada merupakan kompetisi politik di tengah masyarakat. Persaingan partai atau gabungan partai memperebutkan posisi kepala daerah tentu harus mencerminkan interaksi kelompok sosial. Politik kepartaian tentu dengan sendirinya mencerminkan perbedaan orientasi basis sosial pendukung. Sesuai prinsip keterwakilan masyarakat di dalam organisasinya, kelompok sosial jelas harus mendukung politik kepartaian tertentu. Hubungan partai dan basis sosial tidak harus permanen. Sebagai suatu pengelompokan warganegara, partai mewakili perilaku politik masyarakat. Di satu pihak, partai memiliki identitas organisasional yang mewakili citacita dan aspirasi masyarakat. Di pihak lain, masyarakat memiliki identifikasi kuat dengan organisasinya. Hubungan timbal balik yang cenderung bersifat saling memperkuat ini terjadi ketika partai mulai berhasil melakukan institusionalisasi organisasi di masyarakat.

Tetapi, pemilukada telah menampilkan politik kepartaian menurut versinya sendiri. Partai belum berhasil menggerakkan "auto activiteit, rakyat menentukan nasibnya sendiri, memperbaiki nasibnya sendiri." 21 Kesadaran masyarakat tentang pembentukan pemerintahan daerah dan pengawasannya perlu diperkuat. Partai berjalan sendiri dan masyarakat masih menenggangnya. Hal ini yang perlu dibenahi.

${ }^{20}$ EKPPD, EKPOD, EDOB ini sesuai dengan ketentuan pada Pasal 2 PP Nomor 6 Tahun 2008 Tentang Pedoman Evaluasi Penyelenggaraan Pemerintahan Daerah

${ }^{21}$ Terminologi berasal dari Mohammad Hatta, dan penggunaannya dikaitkan dengan pertumbuhan institusi politik lokal otonom.
Dalam proses politik khususnya menjelang penyelenggaraan pemilukada, banyak calon kepala daerah berkampanye dengan memanfaatkan tokoh kharismatik. Partai pendukungnya biasanya akan berusaha membangkitkan semangat massa untuk memenangkan calon, sambil melakukan konsolidasi organisasi. Dalam kaitan membujuk pemilih, kampanye menyediakan panggung perdebatan para calon mengenai isu pemerintahan daerah. Massa mungkin menilai penampilan dan kecerdasan calon. Pendukung bersorak kalau calonnya dapat memainkan strategi menjatuhkan lawan debat. Secara umum perdebatan calon masih dipandang sebagai sebuah pertandingan, bukan penajaman perbedaan program. Calon kepala daerah tampak mengalami kesulitan menegakkan keadilan dalam penyelenggaraan kampanye. Pembatasan banyak dilanggar karena kuatnya pengaruh politik uang. Oleh karena itu banyak sekali dikenal peristilahan yang menyangkut praktek money politics ini seperti misalnya serangan fajar, NPWP (nomor piro wani piro), bitingan/perseorangan, ombyokan/grup, dan lain-lain.

Oleh karena penggunaan uang itu, tidak dapat diketahui secara pasti apakah pemilukada yang melibatkan masyarakat dalam pemilihan kepala daerah secara langsung telah membangun kesadaran tentang penggunaan hak pilih secara rasional. Hal ini karena pemilih sering masih dipengaruhi oleh pertimbangan lain seperti kedekatan personal, kekerabatan, kesamaan etnis ataupun sentimen-sentimen lain. Hal inilah yang kemudian ditengarai sebagai salah satu yang menyebabkan friksi di masyarakat meningkat, dan pada titik tertentu menyebabkan konflik. ${ }^{22}$

\footnotetext{
${ }^{22}$ Kalangan politisi yang menolak pemilukada dan menggantikannya dengan pemilihan kepala daerah oleh DPRD menganggap ancaman kekerasan sosial dan politik masih manifest.
} 
Tabel 2.

Kelebihan dan Kekurangan Hasil Pemilihan Umum Kepala Daerah: Aspek Demokrasi, Akuntabilitas dan Berkelanjutan

\begin{tabular}{|c|c|c|c|}
\hline Aspek & Kelebihan & Kekurangan & Saran \\
\hline Demokrasi & $\begin{array}{l}\text { Masyarakat memiliki } \\
\text { ruang demokrasi yang } \\
\text { luas untuk memilih } \\
\text { kepala daerahnya } \\
\text { sehingga kepala daerah } \\
\text { terpilih memiliki } \\
\text { legitimasi yang kuat } \\
\text { dan bertanggung } \\
\text { jawab penuh kepada } \\
\text { masyarakat. }\end{array}$ & $\begin{array}{l}\text { Proses pemilihan } \\
\text { memakan biaya tidak } \\
\text { sedikit sehingga } \\
\text { dikhawatirkan kepala } \\
\text { daerah terpilih akan } \\
\text { menyalahgunakan } \\
\text { kewenangan anggaran } \\
\text { (APBD) untuk menutupi } \\
\text { ongkos politik yang } \\
\text { sudah dikeluarkan } \\
\text { selama masa kampanye. }\end{array}$ & $\begin{array}{l}\text { Adanya koreksi dari } \\
\text { masyarakat terhadap } \\
\text { birokrasi pemerintah } \\
\text { terutama yang terkait } \\
\text { dengan penggunaan } \\
\text { anggaran (APBD), } \\
\text { melalui kemudahan } \\
\text { dalam mengakses } \\
\text { dokumen-dokumen } \\
\text { publik, transparansi } \\
\text { mekanisme yeng } \\
\text { responsif terhadap } \\
\text { kebutuhan masyarakat }\end{array}$ \\
\hline Akuntabilitas & $\begin{array}{l}\text { Kepala daerah terpilih } \\
\text { memiliki akuntabilitas } \\
\text { dalam pelayanan publik, } \\
\text { kesehatan, pendidikan } \\
\text { dan perekonomian. }\end{array}$ & \begin{tabular}{|l} 
Kualitas pelayanan \\
publik, kesehatan, \\
pendidikan dan \\
perekonomian \\
berkurang bila kepala \\
daerah terpilih \\
cenderung memenuhi \\
target-target politik \\
tertentu dan melakukan \\
korupsi melalui APBD.
\end{tabular} & $\begin{array}{l}\text { Perlunya kontrol } \\
\text { atau pengawasan } \\
\text { publik yang ketat dari } \\
\text { masyarakat, LSM, media } \\
\text { dan DPRD baik melalui } \\
\text { akses keterbukaan } \\
\text { informasi publik } \\
\text { maupun melalui laporan } \\
\text { pertanggungjawaban } \\
\text { kepala daerah. } \\
\end{array}$ \\
\hline Berkelanjutan & $\begin{array}{l}\text { Kepala daerah terpilih } \\
\text { memberikan ruang bagi } \\
\text { aspirasi dan partisipasi } \\
\text { masyarakat untuk turut } \\
\text { serta dalam program } \\
\text { pembangunan dan } \\
\text { melakukan inovasi baru } \\
\text { untuk kesejahteraan } \\
\text { masyarakat }\end{array}$ & $\begin{array}{l}\text { Apabila kepala daerah } \\
\text { tidak mempunyai } \\
\text { program yang } \\
\text { progresif dari program } \\
\text { sebelumnya, bisa } \\
\text { terjadi kemandegan } \\
\text { pembangunan.. }\end{array}$ & $\begin{array}{l}\text { Perlu perbaikan } \\
\text { program kepala daerah } \\
\text { yang disesuaikan } \\
\text { dengan RPJMD, RPJPD } \\
\text { yang bersifat progresif } \\
\text { dan terukur. }\end{array}$ \\
\hline
\end{tabular}

Sumber: diolah dari berbagai sumber

\section{Hasil Pemilukada: Kelebihan dan Kekurangan Pemilukada}

Meskipun sudah hampir sepuluh tahun berjalan, pemilukada yang diharapkan sebagai perwujudan demokrasi dirasakan masih sangat perlu pembenahan. Sistem rekrutmen di dalam partai politik yang kurang transparan dan kadang tidak demokratis, terjadi di masa pencalonan kepala daerah. Praktek money politic, black campaign, penggelembungan suara, pemanfaatan struktur birokrasi, dan masih kuatnya politik identitas masih terjadi. Akibatnya, berdampak pada terpilihnya pemimpin yang kapabilitasnya dipertanyakan, menurunnya kualitas pelayanan publik dan penurunan kualitas tata kelola pemerintahan daerah.

Berdasarkan pada laporan tim pemilukada tahun 2012 dan 2013, kepala daerah terpilih (gubernur, bupati/walikota) 
hasil pemilukada belumlah tentu menunjukkan kinerja yang baik dan akuntabel. Hal ini dikarenakan banyaknya kasus-kasus korupsi yang terjadi yang melibatkan para eksekutif dan legislatif sehingga mereka terjebak di dalamnya. Sementara masyarakat memiliki harapan terhadap kepala daerah terpilih melalui pemilukada sebagai perwujudan demokrasi untuk menghasilkan pemimpin yang berkualitas.

Masih banyak wilayah-wilayah yang dianggap belum melaksanakan kebebasan demokrasi dalam bidang pemerintahan dan birokrasi. Hal ini terjadi dikarenakan masih belum adanya tranparansi pemerintah terhadap dokumen-dokumen publik menyangkut APBD dan perda. Meskipun pemerintah daerah memiliki website resmi, namun masyarakat masih kesulitan untuk mengakses data/ informasi publik yang dibutuhkan meskipun fitur yang ditampilkan tersedia. Selain persoalan keterbukaan informasi publik, lemahnya pengawasan publik dan partisipasi masyarakat terjadi karena peran DPRD yang dirasakan masih sangat kurang. Contohnya masih kurangnya kualitas public hearing dan pengaduan masyarakat di DPRD.

Partisipasi masyarakat di birokrasi pemerintahan juga masih rendah sehubungan dengan pelayanan dasar di bidang pendidikan, kesehatan, dan ekonomi. Hal ini terjadi dikarenakan kurangnya inisiatif birokrasi dalam membentuk forum reguler antara pemerintah dengan masyarakat.

Perlu dipahami bahwa kinerja pemerintahan daerah yang buruk terjadi tidak hanya bergantung pada kondisi sosial geografis suatu daerah tetapi juga ditentukan oleh kemampuan pemimpinnya. Pemimpin (kepala daerah) terpilih diharapkan mampu untuk melakukan inovasi-inovasi dengan memanfaatkan sumber daya yang ada (sumber daya alam, sumber daya manusia, dan kemampuan fiskal daerah). Dengan demikian kepala daerah terpilih sebagai hasil pemilukada diharapkan mampu menciptakan pemerintahan yang akuntabel.

Berikut ini kelebihan dan kekurangan hasil pemilukada ditinjau dari aspek demokrasi, akuntabilitas, dan berkelanjutan yang merupakan hasil pemetaan penulis:

\section{Model Pemilukada Kabupaten/Kota}

Beberapa poin kesimpulan pada penelitian tahun 2013 yang dilakukan oleh tim LIPI memperlihatkan bahwa: Pemilih yang rasional dan otonom di Indonesia dalam konteks pemilukada masih sangat sedikit, Hal ini karena kondisi sosial-ekonomi (yang tecermin dari IPM), kelembagaan daerah yang tecermin dalam kemampuan keuangan daerah dan, mempertimbangkan kondisi sosial-budaya masyarakat yang beragam mengakibatkan derajat dan wujud partisipasi politik masyarakat dalam pemilukada provinsi yang bervariasi. ${ }^{23}$ Selanjutnya, masih dari hasil penelitian tim sebelumnya (2012-2013), terdapat kesimpulan bahwa pemilukada harus tetap dilanjutkan dengan beberapa catatan perbaikan.

Dari dua kesimpulan awal yang mempertimbangkan kemampuan sumber daya manusia dan kemampuan keuangan (LEVEL I sampai LEVEL VI) kita dapat melihat ada dua tawaran yang bisa diajukan. Pertama ada daerahdaerah yang tetap melaksanakan pemilukada langsung seperti saat ini, tentunya dengan catatancatatan perbaikan, kedua, ada daerah-daerah yang untuk sementara perlu pendampingan khusus dalam melaksanakan pemilukada langsung karena peringkat IPM, kondisi sosiokultural dan kemampuan kelembagaanya belum mencukupi untuk itu. Bagi daerah-daerah yang mendapat pendampingan khusus, periode ini dipandang sebagai masa transisi menuju pemilukada langsung dengan harapan bahwa selama masa transisi tersebut terjadi kenaikan IPM dan kemampuan keuangan daerah.

\footnotetext{
${ }^{23}$ Pada Tahun 2013 Tim P2PLIPI(Kurniawati Hastuti Dewi dkk) Mengadakan penelitian mengenai pemilukada di tingkat Provinsi dengan judul: "Evaluasi Format Pemilukada Menuju Pemerintahan Daerah Yang Baik dan Efektif Di Tingkat Provinsi", masih dalam proses cetak.
} 
Tabel 3.

Usulan Perbaikan Penyelenggaraan Pemilu Kepala Daerah

\begin{tabular}{|c|c|c|c|}
\hline Masalah awal & Fakta Objektif & \begin{tabular}{|c|} 
Analisis \\
\end{tabular} & Saran \\
\hline $\begin{array}{l}\text { Ketidaknetralan } \\
\text { penyelenggara } \\
\text { pemilukada (KPU } \\
\text { Kabupaten-Kota) }\end{array}$ & $\begin{array}{l}\text { Seleksi sudah melalui } \\
\text { serangkaian proses } \\
\text { seleksi yang ketat dan } \\
\text { uji kelayakan meliputi } \\
\text { aspek administratif, test } \\
\text { tertulis, tes psikologi, } \\
\text { tes kesehatan, tes } \\
\text { wawancara. }\end{array}$ & $\begin{array}{l}\text { Di beberapa daerah terjadi } \\
\text { ketidakberesan dalam } \\
\text { proses seleksi dan uji } \\
\text { kelayakan. }\end{array}$ & $\begin{array}{l}\text { Penegakan } \\
\text { hukum yang lebih } \\
\text { tegas }\end{array}$ \\
\hline $\begin{array}{l}\text { Terjadinya politik } \\
\text { uang }\end{array}$ & $\begin{array}{l}\text { Sudah ada regulasi } \\
\text { dan instumen yang } \\
\text { melarang dilakukannya } \\
\text { politik uang }\end{array}$ & $\begin{array}{l}\text { Penegakan hukum } \\
\text { pada pelaku politik } \\
\text { uang kurang maksimal, } \\
\text { mekanisme pengawasan } \\
\text { secara operasional kurang } \\
\text { maksimal. Kewenangan } \\
\text { Panwas hanya sebatas } \\
\text { menerima laporan. }\end{array}$ & $\begin{array}{l}\text { Calon kepala } \\
\text { daerah diaudit } \\
\text { kekayaannya oleh } \\
\text { PPATK dan KPK. }\end{array}$ \\
\hline $\begin{array}{l}\text { Partai politik } \\
\text { menarik uang "sewa } \\
\text { perahu" }\end{array}$ & $\begin{array}{l}\text { Tidak ada jaminan } \\
\text { kader asli juga tidak } \\
\text { ditarik "uang sewa } \\
\text { perahu" oleh partai } \\
\text { pengusungnya. }\end{array}$ & $\begin{array}{l}\text { Partai kurang mempunyai } \\
\text { pendekatan ideologis } \\
\text { dalam memilih kandidat. }\end{array}$ & $\begin{array}{l}\text { Partai harus } \\
\text { didorong } \\
\text { mengumumkan } \\
\text { calon kepala } \\
\text { daerah yang akan } \\
\text { diusung sejak dua } \\
\text { tahun sebelum } \\
\text { didaftarkan. } \\
\end{array}$ \\
\hline $\begin{array}{l}\text { Terjadinya } \\
\text { politik dinasti } \\
\text { yang melakukan } \\
\text { penyalahgunaan } \\
\text { kekuasaan. }\end{array}$ & $\begin{array}{l}\text { Sudah ada berbagai } \\
\text { regulasi yang mengatur } \\
\text { sanksi terhadap } \\
\text { penyalahgunaan } \\
\text { kekuasaan. }\end{array}$ & $\begin{array}{l}\text { Proses penegakan } \\
\text { hukumnya yang terlalu } \\
\text { lemah jika berhadapan } \\
\text { dengan penguasa. }\end{array}$ & $\begin{array}{l}\text { Perlu penguatan } \\
\text { aparat penegak } \\
\text { hukum } \\
\text { (Kepolisian, } \\
\text { Kejaksaan, } \\
\text { Pengadilan, KPK) }\end{array}$ \\
\hline
\end{tabular}

Sumber: Diolah dari berbagai sumber

Pada tahun 2012, tim menelaah beberapa aspek dalam pemilukada yang menjadi sumber permasalahan. Pertama, tim menyoroti segi aturan pemilukada yang mencakup beberapa faktor yaitu: syarat pencalonan, syarat calon, dan dukungan anggaran. Kedua, tim menyoroti masalah penyelenggara dimana hal itu terkait erat dengan faktor independensi penyelenggara. Ketiga tim menyoroti penyelenggaraan yang mencakup masalah ketidaknetralan birokrasi, penyusunan daftar pemilih tetap, pencalonan, kampanye, pemungutan suara, distribusi logistik, penetapan dan pelantikan calon terpilih, serta penyelesaian sengketa.

Adapun usulan perbaikan terkait dengan masalah yang didapati secara empiris dan dikaitkan dengan tujuan yang ingin dicapai. Apabila dinarasikan dapat dilihat pada Tabel 3.

Berangkat dari pemaparan analisis sebelumnya kita dapat menyusun model perbaikan pelaksanaan pemilukada sebelumnya. Model ini dirancang dengan membagi periodesasi dari masing-masing proses tahapan. 


\section{Tabel 4.}

Model Perbaikan Penyelenggaraan Pemilukada

\begin{tabular}{|c|c|c|}
\hline Aspek & Saran & Tujuan \\
\hline $\begin{array}{l}\text { Rekrutmen panitia } \\
\text { seleksi (pansel) } \\
\text { penyelenggara }\end{array}$ & $\begin{array}{l}\text { - Pansel harus dipilih dari orang-orang } \\
\text { yang benar-benar berintegritas. } \\
\text { - Pemilihan pansel sedapat mungkin } \\
\text { melibatkan unsur-unsur masyarakat } \\
\text { secara representatif. }\end{array}$ & $\begin{array}{l}\text { - Terciptanya panitia } \\
\text { seleksi penyelenggara } \\
\text { Pemilukada yang netral } \\
\text { dan berintegritas }\end{array}$ \\
\hline $\begin{array}{l}\text { Rekrutmen } \\
\text { penyelenggara }\end{array}$ & $\begin{array}{l}\text { - Perlunya dipilih orang-orang yang } \\
\text { mempunyai integritas, pemahaman dan } \\
\text { kemampuan teknis yang baik. }\end{array}$ & $\begin{array}{l}\text { - Terciptanya } \\
\text { Penyelenggara } \\
\text { Pemilukada yang netral } \\
\text { dan berintegritas } \\
\end{array}$ \\
\hline $\begin{array}{l}\text { Pendaftaran dan } \\
\text { verifikasi calon }\end{array}$ & $\begin{array}{l}\text { - Verifikasi fisik dokumen syarat } \\
\text { administratif harus diperketat dan } \\
\text { adanya transparansi dokumen syarat } \\
\text { administratif calon }\end{array}$ & $\begin{array}{l}\text { - Calon-calon yang } \\
\text { bersaing dalam } \\
\text { pemilukada merupakan } \\
\text { calon-calon kepala } \\
\text { daerah yang baik. }\end{array}$ \\
\hline Kampanye & $\begin{array}{l}\text { - Transparansi sumbangan: penyumbang } \\
\text { dan besaran sumbangan harus } \\
\text { dilaporkan. } \\
\text { - Pembatasan biaya kampanye dalam } \\
\text { konteks besaran sumbangan maksimal } \\
\text { dari tiap penyumbang. }\end{array}$ & $\begin{array}{l}\text { - Tidak terjadi politik } \\
\text { uang. }\end{array}$ \\
\hline Pemungutan Suara & $\begin{array}{l}\text { - Untuk daerah-daerah rawan intimidasi, } \\
\text { manipulasi dan politik uang, perlu } \\
\text { ditambah jumlah Panwas. }\end{array}$ & $\begin{array}{l}\text { - Proses Pemungutan } \\
\text { suara berjalan lancara } \\
\text { dan aman }\end{array}$ \\
\hline Penghitungan suara & $\begin{array}{l}\text { - Form C1 sebagai basis penghitungan } \\
\text { awal di masing-masing TPS diupload di } \\
\text { website resmi KPU. }\end{array}$ & $\begin{array}{l}\text { - Tidak ada manipulasi } \\
\text { dalam proses } \\
\text { penghitungan suara. }\end{array}$ \\
\hline
\end{tabular}

\section{Model Pemilukada Provinsi}

Berangkat dari pertimbangan pemikiran sebagaimana diuraikan sebelumnya, penelitian tahun 2014 ini mengajukan dua skenario pemilukada gubernur sebagai berikut:

\section{Skenario Optimis}

Apabila semua unsur yang diperlukan untuk melaksanakan pemilukada secara langsung sudah tersedia pemilukada langsung gubernur secara serentak bersamaan dengan penyelenggaraan pemilukada bupati walikota, serta pemilu legislatif dan pemilu presiden. ${ }^{24}$ Untuk skenario optimis ini, perlu penyesuaian

${ }^{24}$ Sesuai dengan Putusan MK untuk penyelenggaraan pemilu serentak akan dimulai tahun 2019 baik bersifat regulatif maupun teknis. ${ }^{25}$ Terkait penataan pemilukada serentak ini, Perludem telah melakukan kajian dengan melakukan penggabunganjadwal pemilukada provinsi dan kabupaten kota dengan mempertimbangkan penyelenggaraan pemilu daerah tahun 2021. Untuk itu, tujuh pemilukada gubernur di tahun 2015 dan dua ratus pemilukada kabupaten kota diusulkan untuk diundurkan pada bulan Juni $2016 .^{26}$

\footnotetext{
${ }^{25}$ Salah satu kajian tim Electoral Research Institute adalah mengenai Naskah Akademik Pemilu Serentak yang akan disampaikan pada awal bulan Februari 2015.

${ }^{26}$ Lihat Didik Supriyanto, Khoirunnisa Agustyati, August Mellaz dalam Menata Ulang Jadwal Pilkada Menuju Pemilu Nasional dan Pemilu Daerah, PERLUDEM, 2013, hal.130
} 


\section{Skenario Realistis}

Skenario realistis dilakukan untuk mengantisipasi berbagai kemungkinan yang menghambat pelaksanaan pemilukada gubernur. Misalnya, kesiapan pemerintah pusat dan daerah, pembentukan aturan pelaksanaan, kesiapan masing-masing parpol dan calon kepala daerah yang hendak diusung, serta proses dan penentuan hasil pemilukada. Menyadari karena beragamnya kondisi daerah dan masyarakatnya, bukan mustahil bila kesiapan yang dimaksud tidak dapat diwujudkan oleh semua daerah. Untuk itu, langkah yang mesti dilakukan adalah menyelenggarakan pemilukada gubernur secara asimetris. Penyelenggaraan model ini, akan sangat memperhitungkan kondisi sosialekonomi, sosial-budaya dan sosial politik dari masyarakat di daerah bersangkutan.

\section{Kesimpulan}

Dengan memperhatikan keberagaman kondisi daerah yang mempertimbangkan kemampuan sumberdaya dan kemampuan keuangan (LEVEL I sampai dengan LEVEL VI) sebagaimana tersebut di atas, tim LIPI mengusulkan untuk mempertimbangkan kondisi daerah yang asimetris itu dalam penyelenggaraan pemilukada. Permasalahan penyelenggaraan pemilukada memerlukan intervensi regulatif dan teknis agar pemilukada berproses secara demokratis, penyelenggaraan yang akuntabel, efektif, efisien dalam pembiayaan dan mampu menghasilkan kepala daerah dan wakil kepala daerah yang lebih berkualitas.

\section{Daftar Pustaka}

Charles D. Tarlton, "Symmetry and Assymetry as Element of Federalism: A Theoretical Speculation", the Journal of Politics, Vol. 27 (1965): 869.

David F.J. Campbell, 29 September 2008, halaman 35. http://www.democracyranking. org/downloads/basic_concept_democracy_
ranking_2008_A4.pdf (diakses 11 Oktober 2013).

Didik Supriyanto, Khoirunnisa Agustyati, August Mellaz dalam Menata Ulang Jadwal Pilkada Menuju Pemilu Nasional dan Pemilu Daerah, PERLUDEM, 2013, hal.130

GuillermoA. O'Donnell, “Why the Rule of Law," Journal of Democracy, Vol. 15, No. 4 (Oktober 2004), halaman 37, http://muse.jhu.edu/ journals/jod/summary/v015/15.4odonnell. html (diakses 14 Oktober 2013)

Guillermo O'Donnell, "Human Development, Human Rights, and Democracy," dalam Guillermo O'Donnell, Jorge Vargas Cullell, Osvaldo M. Iazzetta (eds.), The Quality of Democracy Theory and Applications, (USA: University of Notre Dame Press, 2004), halaman 9-10.

Hasyim Asy'ari, "Mempertahankan Pilkada Langsung," Makalah disampaikan pada Focus Group Discussion (FGD), "Evaluasi Format Pilkada", diselenggarakan oleh Pusat Penelitian Politik (P2P), Lembaga Ilmu Pengetahuan Indonesia (LIPI), Jakarta, Kamis, 4 April 2013.

Jennie Litvack, Junaid Ahmad, Richard Bird, "Rethinking Decentralization in Developing Countries", The World Bank Sector Studies Series, September 1998, http://internationalbudget.org/wp-content/ uploads/Rethinking-Decentralization-inDeveloping-Countries.pdf (diakses 10 April 2014), halaman 23.

Kurniawati Hastuti Dewi, "Pemilihan Kepala Daerah Provinsi: Perubahan, Kesinambungan dan Pemetaan Kesiapan Daerah," dalam Kurniawati Hastuti Dewi (ed.), Evaluasi Format Pemilukada Menuju Pemerintahan Daerah yang Baik dan Efektif di tingkat Provinsi, Laporan penelitian tim Pemilukada, Pusat Penelitian Politik LIPI, Jakarta, 2013, tanpa halaman (belum diterbitkan).

Kurniawati Hastuti Dewi, dkk, "Kesimpulan dan Rekomendasi," dalam Kurniawati 
Hastuti Dewi (ed.), Evaluasi Format Pemilukada Menuju Pemerintahan Daerah yang Baik dan Efektif di tingkat Provinsi, Laporan penelitian tim Penelitian Pemilukada, Pusat Penelitian Politik LIPI, Jakarta, 2013, tanpa halaman

PP Nomor 6 Tahun 2008 Tentang Pedoman Evaluasi Penyelenggaraan Pemerintahan Daerah Pasal 2

Prof. Dr. H. Djohermansyah Djohan, MA., Dirjen Otonomi Daerah Kementerian Dalam Negeri Republik Indonesia, “Dinamika Dan Ekses Pilkada Langsung," tanpa halaman

Reza Syawawi dan Khoirunnisa Nur Agustyati, “Membunuh Demokrasi Lokal: Mengembalikan Pemilihan Gubernur Kepada DPRD Provinsi," halaman 16.

Tim Peneliti Jurusan Politik dan Pemerintahan UGM, Laporan Akhir Desentralisasi Asimetris Yang Menyejahterakan: Aceh dan Papua (Yogyakarta: Jurusan Politik dan Pemerintahan Universitas Gadjah Mada, 2012), halaman 9-10.

Tim Penelitian Pemilukada Pusat Penelitian Politik LIPI (Dr. Kurniawati Hastuti Dewi, Prof. Dr. Indria Samego, Dra. Sri Nuryanti, MA., Drs. Afadlal, MA., Pandu Yusina
Adaba S.Ip., Dini Suryani, S.Ip), Evaluasi Format Pemilukada Menuju Pemerintahan Daerah yang Baik dan Efektifdi tingkat Provinsi, Policy Paper, Pusat Penelitian Politik LIPI, Jakarta, 2013, belum diterbitkan.

Tim Penelitian Pemilukada Pusat Penelitian Politik LIPI (Prof. Dr. Indria Samego, Dra. Sri Nuryanti, MA, Dr. Tri Ratnawati, Drs. Afadlal, MA, Pandu Yusina Adaba S.Ip., Dini Suryani S.Ip), “Evaluasi Praktik Pemilukada Langsung di Kabupaten/Kota dan Beberapa Usulan Penyempurnaan ke Depan," Executive Summary, Jakarta, 2012. Tim Penelitian Pemilukada Puslit Politik LIPI tahun 2014 terdiri dari Dr. Kurniawati Hastuti Dewi (Koord), Prof. Dr. Indria Samego, Drs. Afadlal, MA, Sri Nuryanti, SIP,MA, Pandu Yuhsina Adaba, SIP, dan Nyimas Latifah Letty Aziz, SE, MSc

Titi Anggraini dkk, Menata Kembali Pengaturan Pemilukada (Jakarta: Perludem, 2011), halaman 24.

Vedi R. Hadiz, Localising Power in PostAuthoritarian Indonesia: A Southeast Asia Perspective (Stanford California: Stanford University Press, 2010), halaman121. 